\section{Gibberellic Acid Application Timing Affects Fruit Quality of Processing Oranges}

\author{
Matthew W. Fidelibus ${ }^{1}$ and Frederick S. Davies ${ }^{2}$ \\ Horticultural Sciences Department, University of Florida, Gainesville, \\ FL 32611
}

Craig A. Campbell

Field Research and Development, Valent BioSciences, Orlando, FL 32818

Additional index words. Citrus, plant growth regulators, fruit maturity

\begin{abstract}
Gibberellic acid $\left(\mathrm{GA}_{3}\right)$ increases juice yield of processing oranges, but results are inconsistent. Preliminary research suggested that this variability might be related to application timing. Therefore, we conducted an experiment to determine the optimal time to apply $\mathbf{G A}_{3}$ for increasing juice yield of 'Hamlin', 'Pineapple', and 'Valencia' sweet oranges [Citrus sinensis (L.) Osb.]. Mature trees of each cultivar were sprayed with $\approx 10 \mathrm{~L}$ of a solution of $\mathrm{GA}_{3}\left(45 \mathrm{~g} \cdot \mathrm{ha}^{-1} \mathrm{a}\right.$.i. $)$ and organo-silicone surfactant (Silwet, $\left.0.05 \%\right)$ between 2 Sept. and 9 Dec. 1998, and 25 Sept. and 9 Dec. 1999, or remained non-sprayed (control). Generally, the earliest application dates were most effective at maintaining peel puncture resistance above that of control fruit, while the latest application dates resulted in the most green peel color at harvest. Juice yield of 'Hamlin' and 'Valencia', but not 'Pineapple', was increased by $\mathrm{GA}_{3}$ at some application timings and harvest dates in both years. The increase in juice yield was related to time between application and harvest; juice yield of 'Hamlin' was greatest $\approx 2$ months, and 'Valencia' $\approx 5$ months after $\mathbf{G A}_{3}$ application. Treated fruit often had lower juice Brix than non-sprayed fruit, a phenomenon that often paralleled treatment effects on peel color. When treatments did not increase juice yield but reduced juice Brix, then yield of solids was sometimes lower than for non-treated fruit. Treatments generally delayed flowering of 'Pineapple' and 'Valencia' but not 'Hamlin'.
\end{abstract}

Gibberellic acid $\left(\mathrm{GA}_{3}\right)$ has been applied to citrus trees since the late 1950 s to delay peel maturity and thereby prevent, or reduce the severity of, senescence-related peel disorders (Coggins, 1969; Davies, 1986). In the fall, cool temperatures induce peel color break, a green to yellow color change of the flavedo as chloroplasts are converted to chromoplasts (Coggins and Jones, 1977) and peel puncture resistance (PPR) gradually declines (Coggins and Lewis, 1965). Peel senescence may become pronounced, especially if fruit is "stored" on the tree for several months after attaining legal maturity. Tree-stored fruit can retain good internal quality for several months; however, the peel of non- $\mathrm{GA}_{3}$ treated fruit may deteriorate because peel senescence sometimes begins before fruit has attained internal maturity (Coggins, 1969). Senescent peels are typically thought of as a fresh fruit problem (Davies, 1986), but fruit that are mechanically damaged during harvest or those with overly soft or deformed rinds are also culled before processing (Davies et al., 1997).

The potential for $\mathrm{GA}_{3}$ to extend the fresh citrus fruit harvest season recently prompted Florida citrus growers and processors to test the effects of $\mathrm{GA}_{3}$ on processing fruit (Davies

Received for publication 14 Mar. 2001. Accepted for publication 16 July 2001. Florida Agricultural Experiment Station Journal Series no. R-08268.

${ }^{1}$ Graduate Research Assistant.

${ }^{2}$ Professor. et al., 1997). Early reports suggested that $\mathrm{GA}_{3}$ did not affect juice yield (Coggins, 1969; Davies, 1986), but recent research found that $\mathrm{GA}_{3}$-treated fruit yielded up to $10 \%$ more juice than non-treated fruit (Davies et al., 1997, 1999, 2001). Such an increase would be of considerable economic benefit to Florida citrus growers because processed fruit value increases with juice yield and Brix (Braddock, 1999). Therefore, it is desirable to develop management practices for optimization of juice yield by $\mathrm{GA}_{3}$.

The efficacy of $\mathrm{GA}_{3}$ with respect to peel senescence is related to the physiological age of the fruit and to the amount of time between application and harvest (Greenberg et al., 1992). Thus, timing of $\mathrm{GA}_{3}$ application might also be critical for maximization of juice yield (Davies et al., 1999). Late fall application of $\mathrm{GA}_{3}$ can reduce or delay subsequent flowering in citrus (Monselise and Halevy, 1964), a factor that must be considered in timing recommendations. Thus, we conducted research between 1998 and 2000 to determine the effect of $\mathrm{GA}_{3}$ application timing on fruit quality and subsequent flowering of 'Hamlin', 'Pineapple', and 'Valencia' sweet oranges in Florida.

\section{Materials and Methods}

Plant material. Experiments were conducted on 'Hamlin', 'Pineapple', and 'Valencia' orange [Citrus sinensis (L.) Osb.] trees in 1998 and 1999. Trees were on Bitter- sweet (Citrus aurantium L.), sour orange (Citrus aurantium L.), or Carrizo citrange [Citrus sinensis (L.) Osb. X Poncirus trifoliata (L.) Raf.] rootstocks, respectively. 'Hamlin' and 'Pineapple' trees were planted in 1981 and 'Valencia' trees in 1975. All trees were located in a commercial orchard near Arcadia, Fla. Experimental trees were selected on the basis of uniform size, appearance, and estimated crop load and were surrounded by nonexperimental border trees.

Application of $G A_{3}$. A backpack sprayer (Solo, Newport News, Va.) was used to apply $\approx 10 \mathrm{~L}$ of a $\mathrm{GA}_{3}$ (ProGibb, Valent BioSciences, Chicago; $45 \mathrm{~g} \cdot \mathrm{ha}^{-1}$ a.i.) and organo-silicone surfactant (Silwet, Setre Chemical Co., Memphis, Tenn.; $0.05 \% \mathrm{v} / \mathrm{v}$ ) solution to each tree. Applications were made on 12 different mature 'Hamlin' and 'Pineapple' orange trees on 2 Sept., 25 Sept., 10 Oct. (before color break; hue angle $\geq 120^{\circ}$ ) or 12 Nov. 1998 (after color break; hue angle $\approx 107^{\circ}$ ) and 25 Sept. (before color break; hue angle $\geq 120^{\circ}$ ), 27 Oct. (about color break; hue angle $\approx 110^{\circ}$ ), or 19 Nov. 1999 (after color break; hue angle $\approx 100^{\circ}$ ). The same solution was also applied to 12 different 'Valencia' orange trees on 25 Sept., 10 Oct., 12 Nov. (before color break; hue angle $>120^{\circ}$ ) or 8 Dec. 1998 (after color break; hue angle $\approx 108^{\circ}$ ) and 25 Sept., 27 Oct. (before color break; hue angle $\geq 120^{\circ}$ ), 19 Nov. (about color break; hue angle $\approx 110^{\circ}$ ) or 9 Dec. 1999 (after color break; hue angle $\approx 105^{\circ}$ ). Each year, 12 additional 'Hamlin', 'Pineapple', and 'Valencia' trees remained nonsprayed (controls). The experiment consisted of a randomized complete-block design with five treatments and 12 trees per treatment.

Each tree received the same treatment both years except for 1999 when 'Hamlin' orange trees did not receive an early September spray and 'Pineapple' orange trees were not tested after the grower applied $\mathrm{GA}_{3}$ to the entire 'Pineapple' grove. Application timing and the number of replicates used were suggested by previous studies (Davies et al., 1997, 1999).

Fruit quality tests. Fruit were harvested two or three times each season during the normal harvest period of each cultivar. At each harvest, two samples of fruit were randomly collected at a 1- to 2-m height around each tree. One sample consisted of 10 fruit that were washed, air-dried, and evaluated for peel color, peel puncture resistance (PPR), fruit diameter, and peel thickness. Peel color (hue) was measured with a Minolta chroma meter (Minolta Inc., Ramsey, N.J.). Peel puncture resistance was measured with an AccuForce ${ }^{\circledR}$ force gauge (Ametek, Largo, Fla.) that recorded the peak force sustained by the peel when subjected to a cylindrical, 0.5-mm-diameter, steel probe. Fruit diameter and peel thickness were measured at the fruit equator with calipers. Average peel color and PPR of each fruit were determined from three measurements per fruit (made equidistant around the fruit equator). Another sample of $\approx 10 \mathrm{~kg}$ of fruit was collected from each tree and transported to the Dept. of Citrus at Lake Alfred, Fla., for juice yield and quality tests. Each sample was juiced according to Florida State 
test standards (Wardowski et al., 1995) using an FMC Model 091 juice extractor. Juice weight, Brix, acid, and ratio were determined using standard techniques (Wardowski et al., 1995).

Flowering. On 1 Apr. 1999, all trees were inspected and rated according to their stage of flowering. A scale of 1 to 10 was used to classify the stage of flowering with $1=$ no open flowers, $2=25 \%$ open flowers, $3=50 \%$ open flowers, $4=75 \%$ open flowers, $5=$ full bloom, $6=25 \%$ petal fall, $7=50 \%$ petal fall, $8=75 \%$ petal fall, $9=100 \%$ petal fall, $10=$ initial fruit set. Flowering was not evaluated in 2000.

Experimental design and analysis. The experiment was established as a randomized complete-block design, but there were no block effects (data not shown), so the data were reanalyzed as a completely randomized design. Data were subjected to the general linear model procedure (SAS Institute, Cary, N.C.) for analysis of variance (ANOVA). To test whether the variables changed over time, data were subjected to ANOVA as a split-plot in time with treatments as the main plot and harvest time as the subplot. The effect of harvest time was significant for each variable $(P \leq 0.05$; data not shown), and data were then subjected to analysis of variance by date and treatment. When treatment effects were significant, treatment means were separated within dates using Duncan's new multiple range test (DNMRT). To examine relationships among variables, fruit quality data were subjected to regression analysis using PROC REG (SAS Institute Inc.).

\section{Results and Discussion}

Peel hue angle $\left(\mathrm{H}^{\circ}\right)$ and PPR decreased with time for each cultivar during both seasons (Tables 1-5). Fruit from $\mathrm{GA}_{3}$-treated trees usually had higher $\mathrm{H}^{\circ}$ (were more green) and greater PPR than fruit of control trees; however, application timing affected both variables. For example, peel $\mathrm{H}^{\circ}$ of 'Hamlin' and 'Pineapple' fruit treated with $\mathrm{GA}_{3}$ in early September was often comparable to that of non-sprayed fruit by the final harvest (Tables 1-3), whereas fruit receiving late sprays generally had greener peels than other fruit, particularly for late harvests. In contrast, the highest PPR was usually achieved with an early $\mathrm{GA}_{3}$ application, even for late harvests (Tables $1-5)$.

Thus, peel color development may be inhibited or reversed (Huff, 1984), even by postcolor break sprays, but the progressive decrease in PPR can best be slowed by $\mathrm{GA}_{3}$ applied before color break. Moreover, the $\mathrm{GA}_{3}$ effect on PPR is longer lasting than its effect on peel color (if applied early enough). These findings are consistent with the effects of $\mathrm{GA}_{3}$ on puffing of mandarin and creasing of orange, where early application reduces the breakdown of albedo tissue without affecting peel color development (Greenberg et al., 1992; Monselise et al., 1976; Pozo et al., 2000). Therefore, $\mathrm{GA}_{3}$ effects on peel hue and PPR, although often positively correlated (Coggins and Lewis, 1965), appear to be independent.
Table 1. Peel color (hue angle) and peel puncture resistance (PPR) of 'Hamlin' oranges sprayed with GA 3 (45 g.ha ${ }^{-1}$ a.i.) on different dates, Arcadia, Fla., 1998-99.

\begin{tabular}{|c|c|c|c|c|c|c|}
\hline \multirow{2}{*}{$\begin{array}{l}\mathrm{GA}_{3} \text { application } \\
\text { date, } 1998\end{array}$} & \multicolumn{6}{|c|}{ Harvest date } \\
\hline & 8 Dec. 1998 & 20 Jan. 1999 & 17 Feb. 1999 & 8 Dec. 1998 & 20 Jan. 1999 & 17 Feb. 1999 \\
\hline & \multicolumn{3}{|c|}{ - } & \multicolumn{3}{|c|}{ - } \\
\hline 2 Sept. & $106.4 \mathrm{c}^{\mathrm{z}}$ & & $81.7 \mathrm{bc}$ & $5.4 \mathrm{~b}$ & $3.8 \mathrm{c}$ & $3.9 \mathrm{a}$ \\
\hline $25 \mathrm{Sc}$ & & & & 6.0 & & 4.0 \\
\hline 10 Oct. & $112.1 \mathrm{ab}$ & $95.5 \mathrm{~b}$ & $85.6 \mathrm{~b}$ & $5.8 \mathrm{a}$ & $4.5 \mathrm{a}$ & $4.0 \mathrm{a}$ \\
\hline 12 Nov. & 109.8 b & 101.9 a & $90.9 \mathrm{a}$ & $5.2 \mathrm{~b}$ & $4.2 \mathrm{~b}$ & $4.0 \mathrm{a}$ \\
\hline Nonsprayed & $99.2 \mathrm{~d}$ & $82.8 \mathrm{e}$ & $80.8 \mathrm{c}$ & $4.5 \mathrm{c}$ & $3.4 \mathrm{~d}$ & $3.6 \mathrm{~b}$ \\
\hline
\end{tabular}

${ }^{2}$ Means followed by a different letter are significantly different within columns by Duncan's new multiple range test, $P \leq 0.05$. Ten fruit were collected from each of 12 trees/treatment. Three measurements were made equidistant around the fruit equator.

Table 2. Peel color (hue angle) and peel puncture resistance (PPR) of 'Hamlin' oranges sprayed with $\mathrm{GA}_{3}\left(45 \mathrm{~g} \cdot \mathrm{ha}^{-1}\right.$ a.i. $)$ on different dates, Arcadia, Fla., 1999-2000.

\begin{tabular}{|c|c|c|c|c|}
\hline \multirow{2}{*}{$\begin{array}{l}\mathrm{GA}_{3} \text { application } \\
\text { date, } 1999\end{array}$} & \multicolumn{4}{|c|}{ Harvest date } \\
\hline & 7 Dec. 1999 & 5 Jan. 2000 & 7 Dec. 1999 & 5 Jan. 2000 \\
\hline & \multicolumn{2}{|c|}{----- Hue angle $\left(^{\circ}\right)$} & \multicolumn{2}{|c|}{ 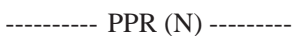 } \\
\hline 25 Sept. & $104.7 \mathrm{a}^{\mathrm{z}}$ & $90.1 \mathrm{~b}$ & $6.1 \mathrm{a}$ & $4.9 \mathrm{a}$ \\
\hline 27 Oct. & $103.9 \mathrm{a}$ & $93.2 \mathrm{a}$ & $5.3 \mathrm{~b}$ & $4.7 \mathrm{a}$ \\
\hline 19 Nov. & $95.8 \mathrm{~b}$ & $89.8 \mathrm{~b}$ & $4.7 \mathrm{c}$ & $4.4 \mathrm{~b}$ \\
\hline Nonsprayed & $85.6 \mathrm{c}$ & $77.4 \mathrm{c}$ & $4.0 \mathrm{~d}$ & $3.5 \mathrm{c}$ \\
\hline
\end{tabular}

${ }^{2}$ Means followed by a different letter are significantly different within columns by Duncan's new multiple range test, $P \leq 0.05$. Ten fruit were collected from each of 12 trees/treatment. Three measurements were made equidistant around the fruit equator.

Table 3. Peel color (hue angle) and peel puncture resistance (PPR) of 'Pineapple' oranges sprayed with $\mathrm{GA}_{3}\left(45 \mathrm{~g} \cdot \mathrm{ha}^{-1}\right.$ a.i. $)$ on different dates, Arcadia, Fla., 1998-99.

\begin{tabular}{|c|c|c|c|c|}
\hline \multirow{2}{*}{$\begin{array}{l}\mathrm{GA}_{3} \text { application } \\
\text { date, } 1998\end{array}$} & \multicolumn{4}{|c|}{ Harvest date, 1999} \\
\hline & 3 Feb. & $24 \mathrm{Feb}$. & 3 Feb. & 24 Feb. \\
\hline & \multicolumn{2}{|c|}{--- Hue angle $\left(^{\circ}\right)$} & \multicolumn{2}{|c|}{ PPR (N) - } \\
\hline 2 Sept. & $84.8 b^{2}$ & $79.4 \mathrm{~b}$ & $5.2 \mathrm{a}$ & $5.1 \mathrm{a}$ \\
\hline 25 Sept. & $82.3 \mathrm{~b}$ & $77.4 \mathrm{~b}$ & $4.0 \mathrm{~b}$ & $3.9 \mathrm{~b}$ \\
\hline 10 Oct. & $96.6 \mathrm{a}$ & $89.0 \mathrm{a}$ & $5.2 \mathrm{a}$ & $5.0 \mathrm{a}$ \\
\hline 12 Nov. & $95.3 \mathrm{a}$ & $91.1 \mathrm{a}$ & $4.7 \mathrm{ab}$ & $4.5 \mathrm{ab}$ \\
\hline Nonsprayed & $78.9 \mathrm{~b}$ & $74.7 \mathrm{~b}$ & $4.0 \mathrm{~b}$ & $3.9 \mathrm{~b}$ \\
\hline
\end{tabular}

${ }^{2}$ Means followed by a different letter are significantly different within columns by Duncan's new multiple range test, $P \leq 0.05$. Ten fruit were collected from each of 12 trees/treatment. Three measurements were made equidistant around the fruit equator.

Table 4. Peel color (hue angle) and peel puncture resistance (PPR) of 'Valencia' oranges sprayed with $\mathrm{GA}_{3}\left(45 \mathrm{~g} \cdot \mathrm{ha}^{-1}\right.$ a.i.) on different dates, Arcadia, Fla., 1998-99.

\begin{tabular}{|c|c|c|c|c|}
\hline \multirow{2}{*}{$\begin{array}{l}\mathrm{GA}_{3} \text { application } \\
\text { date, } 1998\end{array}$} & \multicolumn{4}{|c|}{ Harvest date, 1999} \\
\hline & 23 Apr. & 13 May & 23 Apr. & 13 May \\
\hline & \multicolumn{4}{|c|}{------ Hue angle $\left(^{\circ}\right)$------ } \\
\hline 25 Sept. & $91.0 \mathrm{bc}^{2}$ & $91.8 \mathrm{~b}$ & $7.0 \mathrm{a}$ & $6.4 \mathrm{a}$ \\
\hline $10 \mathrm{O}$ & $90.0 \mathrm{c}$ & $88.6 \mathrm{c}$ & $6.4 \mathrm{bc}$ & $5.8 \mathrm{~b}$ \\
\hline $12 \mathrm{~N}$ & $93.7 \mathrm{~b}$ & $93.8 \mathrm{ab}$ & $6.5 \mathrm{~b}$ & $6.0 \mathrm{~b}$ \\
\hline $8 \mathrm{Dec}$ & $97.5 \mathrm{a}$ & $95.4 \mathrm{a}$ & $6.6 \mathrm{~b}$ & $6.1 \mathrm{ab}$ \\
\hline Non-sprayed & $85.4 \mathrm{~d}$ & $85.7 \mathrm{~d}$ & $6.1 \mathrm{c}$ & $5.6 \mathrm{~b}$ \\
\hline
\end{tabular}

${ }^{2}$ Means followed by a different letter are significantly different within columns by Duncan's new multiple range test, $P \leq 0.05$. Ten fruit were collected from each of 12 trees/treatment. Three measurements were made equidistant around the fruit equator. 
Gibberellic acid effects on peel senescence were less persistent for 'Hamlin' or 'Pineapple' (Tables 1-3) than for 'Valencia' (Tables $4-5$ ); $\approx 5-6$ months vs. 7-8 months, respectively.

Juice yield remained relatively constant among harvest dates for each cultivar (Tables $6,7)$. However, there were significant treatment effects on juice yield of 'Hamlin' and 'Valencia' oranges on certain harvests during both seasons. 'Hamlin' oranges sprayed on 25 Sept. 1998 yielded more juice than nonsprayed fruit on 8 Dec. 1998. On 20 Jan. 1999, fruit sprayed on 10 Oct. 1998 yielded more juice than fruit treated on 2 Sept. 1998 but not more than non-sprayed fruit (Table 6). There were no treatment effects on juice yield on $17 \mathrm{Feb}$ 1999. Thus, the greatest juice yield for 'Hamlin' oranges was achieved when fruit were harvested between 1.5 to 3 months after application. The following season, there were no significant treatment effects on 7 Dec. 1999. However, on 5 Jan. 2000, fruit treated on 27 Oct. $1999(\approx 2$ months before harvest) yielded more juice than nonsprayed fruit or fruit treated on 12 Nov. 1999.

Gibberellic acid application on 12 Nov. 1998 increased 'Valencia' juice yield over non-sprayed fruit when harvested on $23 \mathrm{Apr}$. 1999 , $\approx 5$ months later (Table 7), but treatments did not affect juice yield on 13 May 1999. The following season, 'Valencia' fruit sprayed on 27 Oct. or 19 Nov. 1999 yielded more juice on 10 Mar. 2000 than fruit sprayed on 25 Sept. or non-sprayed fruit (Table 7). On 10 May 2000, fruit sprayed on 9 Dec. yielded more juice than nonsprayed fruit, although fruit sprayed on 25 Sept. yielded less juice than other $\mathrm{GA}_{3}$ application times and non-sprayed fruit. Thus, $\mathrm{GA}_{3}$ increased juice yield of 'Valencia' oranges in 1998-99 and 1999_ 2000 when applied $\approx 5$ months before harvest. Juice yield of 'Pineapple' oranges was not affected by $\mathrm{GA}_{3}$ application during the one season tested (data not shown).

The magnitude of the juice yield increase $(\approx 4 \%$, standardized to control) was comparable to that observed in previous studies (Davies et al., 1997, 1999, 2001). Time between application and harvest affected the amount of juice increase because the optimal application time advanced with harvest date for 'Hamlin' in 1998-99 and for 'Valencia' during both seasons. Juice yield of 'Hamlin' responded to a shorter time between application and harvest than did 'Valencia', which was also observed for peel color and PPR. Although $\mathrm{GA}_{3}$ did not enhance juice yield of 'Hamlin' nearly as frequently as it did for 'Valencia' (relative to controls, only the 25 Sept. 1998 application increased juice yield of 'Hamlin' on 8 Dec. 1998), these findings agree with those of Davies et al. (1997), who observed that $\mathrm{GA}_{3}$ applied in mid-September to two different groves increased juice yield of 'Hamlin' in both groves in mid-December but not in January or February. Apparently, application date is more critical for 'Hamlin' than for 'Valencia'. The fact that $\mathrm{GA}_{3}$ did not affect juice yield of 'Pineapple' is surprising because $\mathrm{GA}_{3}$ substantially increased juice yield of this

Table 5. Peel color (hue angle) and peel puncture resistance (PPR) of 'Valencia' oranges sprayed with GA (45 g.ha ${ }^{-1}$ a.i.) on different dates, Arcadia, Fla., 2000.

\begin{tabular}{|c|c|c|c|c|c|c|}
\hline \multirow{2}{*}{$\begin{array}{l}\mathrm{GA}_{3} \text { application } \\
\text { date, } 1999\end{array}$} & \multicolumn{6}{|c|}{ Harvest date } \\
\hline & 10 Feb. & 10 Mar. & 10 May & 10 Feb. & 10 Mar. & 10 May \\
\hline & \multicolumn{3}{|c|}{----- Hue angle $\left(^{\circ}\right)$} & \multicolumn{3}{|c|}{--------------- PPR (N) ---------------' } \\
\hline 25 Sept. & $81.4 c^{z}$ & $80.0 \mathrm{c}$ & $79.9 \mathrm{~b}$ & $5.3 \mathrm{c}$ & $5.0 \mathrm{~d}$ & $5.1 \mathrm{c}$ \\
\hline 27 Oct. & $104.8 \mathrm{a}$ & $98.2 \mathrm{a}$ & $93.7 \mathrm{a}$ & $7.4 \mathrm{a}$ & $7.4 \mathrm{a}$ & $6.5 \mathrm{a}$ \\
\hline 19 Nov. & $102.5 \mathrm{a}$ & $97.9 \mathrm{a}$ & $93.0 \mathrm{a}$ & $6.1 \mathrm{~b}$ & $6.2 \mathrm{~b}$ & $5.8 \mathrm{~b}$ \\
\hline 9 Dec. & $98.7 \mathrm{~b}$ & $93.6 \mathrm{~b}$ & $92.3 \mathrm{a}$ & $5.8 \mathrm{~b}$ & $5.7 \mathrm{c}$ & $5.8 \mathrm{~b}$ \\
\hline Non-sprayed & $81.1 \mathrm{c}$ & $80.0 \mathrm{c}$ & $79.0 \mathrm{~b}$ & $5.3 \mathrm{c}$ & $5.3 \mathrm{~d}$ & $5.3 \mathrm{c}$ \\
\hline
\end{tabular}

${ }^{\text {z} M e a n s ~ f o l l o w e d ~ b y ~ a ~ d i f f e r e n t ~ l e t t e r ~ w i t h i n ~ c o l u m n s ~ a r e ~ s i g n i f i c a n t l y ~ d i f f e r e n t ~ w i t h i n ~ c o l u m n s ~ b y ~ D u n c a n ' s ~}$ new multiple range test, $P \leq 0.05$. Ten fruit were collected from each of 12 trees/treatment. Three measurements were made equidistant around the fruit equator.

Table 6. Juice yield of 'Hamlin' oranges sprayed with $\mathrm{GA}_{3}\left(45 \mathrm{~g} \cdot \mathrm{ha}^{-1}\right.$ a.i. $)$ on different dates, Arcadia, Fla., 1998-99, 1999-2000.

\begin{tabular}{|c|c|c|c|c|c|c|}
\hline \multirow{3}{*}{$\begin{array}{l}\mathrm{GA}_{3} \text { application } \\
\text { date, } 1998\end{array}$} & \multicolumn{3}{|c|}{ 1998-99 Season } & \multirow{3}{*}{$\begin{array}{c}\mathrm{GA}_{3} \text { application } \\
\text { date, } 1999\end{array}$} & \multicolumn{2}{|c|}{ 1999-2000 Season } \\
\hline & \multicolumn{3}{|c|}{ Harvest date, 1998-99 } & & \multicolumn{2}{|c|}{ Harvest date, 1999-2000 } \\
\hline & 8 Dec. & 20 Jan. & 17 Feb. & & 7 Dec. & 5 Jan. \\
\hline & \multicolumn{3}{|c|}{----- Juice yield (\%wt/wt) ----- } & & \multicolumn{2}{|c|}{-- Juice yield (\%wt/wt) -- } \\
\hline 2 Sept. & $59.4 b^{z}$ & $58.9 \mathrm{~b}$ & $59.5 \mathrm{a}$ & --- & --- & --- \\
\hline 25 Sept. & $62.1 \mathrm{a}$ & $60.6 \mathrm{ab}$ & $60.4 \mathrm{a}$ & 25 Sept. & $59.1 \mathrm{a}$ & $58.5 \mathrm{ab}$ \\
\hline 10 Oct. & $60.8 \mathrm{ab}$ & $61.5 \mathrm{a}$ & $60.3 \mathrm{a}$ & 27 Oct. & 59.9 a & $59.1 \mathrm{a}$ \\
\hline 12 Nov. & $61.0 \mathrm{ab}$ & $59.3 \mathrm{ab}$ & $60.1 \mathrm{a}$ & 19 Nov. & $58.0 \mathrm{a}$ & $57.3 \mathrm{~b}$ \\
\hline Non-sprayed & $59.5 \mathrm{~b}$ & $60.4 \mathrm{ab}$ & $59.3 \mathrm{a}$ & Nonsprayed & $58.6 \mathrm{a}$ & $57.5 \mathrm{~b}$ \\
\hline
\end{tabular}

${ }^{\text {zMeans followed by a different letter are significantly different within columns by Duncan's new multiple }}$ range test, $P \leq 0.05$. Means of a $10-\mathrm{kg}$ fruit sample/tree from 12 trees/treatment.

Table 7. Juice yield of 'Valencia' oranges sprayed with $\mathrm{GA}_{3}\left(45 \mathrm{~g} \cdot \mathrm{ha}^{-1}\right.$ a.i. $)$ on different dates, Arcadia, Fla., 1998-99, 1999-2000.

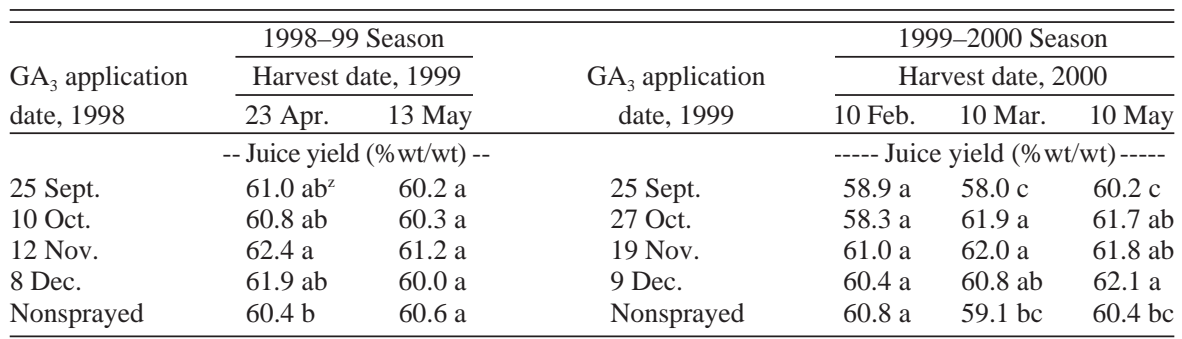

${ }^{2}$ Means followed by a different letter are significantly different within columns by Duncan's new multiple range test, $P \leq 0.05, \mathrm{n}=12$. Means of a $10-\mathrm{kg}$ fruit sample/tree from 12 trees/treatment.

cultivar in a previous study (Davies et al., 1997). However, $\mathrm{GA}_{3}$ was less effective in modifying fruit quality variables of 'Pineapple' fruit compared with 'Hamlin' or 'Valencia'.

How $\mathrm{GA}_{3}$ increased orange juice yield is unknown. Autumn application of $\mathrm{GA}_{3}$ increased late-season juice yield of satsuma mandarin (Citrus unshiu Marc.) and 'Sunburst' tangerine $[(C$. reticulata Blanco $\times C$. paradisi Macf.) $\mathrm{x} C$. reticulata $\mathrm{Blanco}]$ (Garcia-Luis et al., 1985; Pozo et al., 2000) by suppressing the normal decrease in juice content. In contrast, we found that $\mathrm{GA}_{3}$ increased juice yield of 'Hamlin' and 'Valencia' relatively early in the season when juice yield was not appreciably declining. Moreover, $\mathrm{GA}_{3}$ treated 'Hamlin' and 'Valencia' fruit always had the highest juice yield of the season.

Gibberellic acid reduced the peel : pulp ratio of mandarins (Garcia-Luis et al., 1985; Pozo et al., 2000), but in our study neither fruit diameter nor peel thickness were affected by $\mathrm{GA}_{3}$ (data not shown). Therefore, $\mathrm{GA}_{3}$ probably did not increase juice yield by increasing pulp volume. Differential water loss between $\mathrm{GA}_{3}$ and non-GA $\mathrm{G}_{3}$ treated fruit probably can- not account for differential juice yield because $\mathrm{GA}_{3}$ did not affect peel wax content (El-Otmani et al., 1986) or fruit water loss (El-Otmani and Coggins, 1991), although it did affect wax composition (El-Otmani et al., 1986).

An alternative hypothesis is that $\mathrm{GA}_{3}$ altered the physical or rheological properties of the fruit such that the efficiency of mechanical juice extraction was enhanced. Oranges with senescent peels sometimes burst during juice extraction (J. Keithly, personal communication), possibly allowing some pulp to escape the juice stream. Thus, fruit having $\mathrm{GA}_{3}-$ strengthened peels might lose less juice during extraction than nonsprayed fruit having mechanically weaker peels. In an earlier study, PPR was highly correlated with juice yield (Davies et al., 1997), providing further evidence that $\mathrm{GA}_{3}$ might enhance juice yield by increasing peel strength. However, in the present study, there was no consistent correlation between PPR and juice yield. Nevertheless, we are presently testing whether $\mathrm{GA}_{3}$ affects various fruit rheological properties that might affect juice yield.

Juice Brix increased during the harvest season for all cultivars as expected. However, 
some $\mathrm{GA}_{3}$ treatments resulted in lower juice Brix at harvest during both seasons for all cultivars (Tables 8, 9). 'Hamlin' oranges treated with $\mathrm{GA}_{3}$ on 25 Sept., 10 Oct., and 12 Nov. 1998 had lower juice Brix than control fruit on 8 Dec. 1998. On 20 Jan. 1999, the 10 Oct. and 12 Nov. $1998 \mathrm{GA}_{3}$ treatments reduced juice Brix, but only the 12 Nov. 1998 application resulted in lower Brix by 17 Feb. 1999. Thus, $\mathrm{GA}_{3}$ reduced 'Hamlin' juice Brix within 1 month of application and the effect persisted for 2.5 to 3 months. In 1999-2000, only $\mathrm{GA}_{3}$ applied $\approx 2$ months before harvest reduced juice Brix on 7 Dec., but $\mathrm{GA}_{3}$ applied on all dates reduced juice Brix on 5 Jan., which was between 2 and 3 months after application.

Effects of $\mathrm{GA}_{3}$ on 'Valencia' juice Brix lasted longer than for 'Hamlin'. All GA 3 treatments resulted in lower 'Valencia' juice Brix than controls for fruit harvested on $23 \mathrm{Apr}$. and 13 May 1999, except for fruit treated on 27 Oct. 1998 that did not have lower juice Brix than control fruit on 13 May. Therefore, $\mathrm{GA}_{3}$ effects persisted up to 7 months. Similar results were observed in 2000 when $\mathrm{GA}_{3}$ applied between 27 Oct. and 9 Dec. 1999 generally reduced juice Brix from 10 Feb. through 10 May. As observed for other fruit quality variables measured, 'Pineapple' juice Brix was

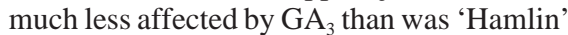
or 'Valencia', with only the 12 Nov. 1998 application date reducing juice Brix on $3 \mathrm{Feb}$. 1999 (data not shown).

Most studies indicate that $\mathrm{GA}_{3}$ does not affect juice Brix (Coggins, 1969; Davies, 1986; Davies et al., 1997). However, Coggins and Hield (1958) found that green peel color increased and juice Brix decreased related to the amount of $\mathrm{GA}_{3}$ applied to 'Valencia' oranges. Cary (1975) also reported that gibberellin sprays accentuated regreening and reduced juice Brix of 'Valencia' oranges when both mature and small fruit were on the tree. Sites and Reitz (1950) found that 'Valencia' oranges with green peels tended to have lower total soluble solids than fruit with yellow- or orange-colored peels. Similarly, Pozo et al. (2000) reported that $\mathrm{GA}_{3}$ sprays temporarily reduced 'Sunburst' tangerine juice Brix. Thus, our findings add to the evidence that fruit having natural or $\mathrm{GA}_{3}$-induced green peel color may also have lower juice Brix.

It is not known how $\mathrm{GA}_{3}$ could reduce juice Brix. Brix was not related to juice yield $\left(\mathrm{r}^{2} \cong 0\right)$, so the reduction in Brix did not occur by dilution. However, there was an inverse association between green peel color and juice Brix. Application dates that resulted in the highest peel hue angles (most green color) usually had the lowest juice Brix, whereas control fruit, which usually had the lowest peel hue angles, typically had the highest juice Brix. Peel hexose levels are inversely related to peel chlorophyll levels (Huff, 1984) and $\mathrm{GA}_{3}$ increased navel orange peel respiration (Lewis et al., 1967). Perhaps $\mathrm{GA}_{3}$ affects the peel vs. the pulp sink strength. We are currently conducting research to determine how $\mathrm{GA}_{3}$ might affect juice Brix.

The value of fruit grown for processing in Florida is based on the weight of solids $\left({ }^{\circ}\right.$ Brix

Table 8. Juice Brix of 'Hamlin' oranges sprayed with $\mathrm{GA}_{3}\left(45 \mathrm{~g} \cdot \mathrm{ha}^{-1}\right.$ a.i.) on different dates, Arcadia, Fla., 1998-99, 1999-2000.

\begin{tabular}{|c|c|c|c|c|c|c|}
\hline \multirow{3}{*}{$\begin{array}{l}\mathrm{GA}_{3} \text { application } \\
\text { date, } 1998\end{array}$} & \multicolumn{3}{|c|}{ 1998-99 Season } & \multirow{3}{*}{$\begin{array}{c}\mathrm{GA}_{3} \text { application } \\
\text { date, } 1999\end{array}$} & \multirow{2}{*}{\multicolumn{2}{|c|}{$\begin{array}{c}\text { 1999-2000 Season } \\
\text { Harvest date }\end{array}$}} \\
\hline & \multicolumn{3}{|c|}{ Harvest date } & & & \\
\hline & 8 Dec. & 20 Jan. & $17 \mathrm{Feb}$. & & 7 Dec. 1999 & 5 Jan. 2000 \\
\hline & \multicolumn{3}{|c|}{---- Juice Brix $\left(^{\circ}\right)$} & & \multicolumn{2}{|c|}{---- Juice Brix $\left({ }^{\circ}\right)$---- } \\
\hline 2 Sept. & $10.0 \mathrm{ab}^{\mathrm{z}}$ & $11.2 \mathrm{a}$ & $12.0 \mathrm{a}$ & --- & --- & --- \\
\hline 25 Sept. & $9.8 \mathrm{bc}$ & $11.0 \mathrm{ab}$ & $12.0 \mathrm{a}$ & 25 Sept. & $9.9 \mathrm{~b}$ & $10.6 \mathrm{~b}$ \\
\hline 10 Oct. & $9.7 \mathrm{c}$ & $10.8 \mathrm{bc}$ & $11.6 \mathrm{ab}$ & 27 Oct. & $10.2 \mathrm{ab}$ & $10.7 \mathrm{ab}$ \\
\hline 12 Nov. & $9.7 \mathrm{c}$ & $10.6 \mathrm{c}$ & $11.4 \mathrm{~b}$ & 19 Nov. & $10.3 \mathrm{a}$ & $10.6 \mathrm{~b}$ \\
\hline Nonsprayed & $10.1 \mathrm{a}$ & $11.2 \mathrm{a}$ & $11.8 \mathrm{a}$ & Nonsprayed & $10.4 \mathrm{a}$ & $11.0 \mathrm{a}$ \\
\hline
\end{tabular}

${ }^{2}$ Means followed by a different letter are significantly different within columns by Duncan's new multiple range test, $P \leq 0.05$. Means of a $4 \mathrm{~L} /$ tree juice sample from 12 trees/treatment.

Table 9. Juice Brix of 'Valencia' oranges sprayed with $\mathrm{GA}_{3}\left(45 \mathrm{~g} \cdot \mathrm{ha}^{-1}\right.$ a.i.) on different dates, Arcadia, Fla., 1998-99, 1999-2000.

\begin{tabular}{|c|c|c|c|c|c|c|}
\hline \multirow{3}{*}{$\begin{array}{l}\mathrm{GA}_{3} \text { application } \\
\text { date, } 1998\end{array}$} & \multicolumn{2}{|c|}{ 1998-99 Season } & \multirow{3}{*}{$\begin{array}{c}\mathrm{GA}_{3} \text { application } \\
\text { date, } 1999 \\
\end{array}$} & \multicolumn{3}{|c|}{ 1999-2000 Season } \\
\hline & \multicolumn{2}{|c|}{ Harvest date, 1999} & & \multicolumn{3}{|c|}{ Harvest date, 2000} \\
\hline & 23 Apr. & 13 May & & 10 Feb. & 10 Mar. & 10 May \\
\hline & \multicolumn{2}{|c|}{--- Juice Brix $\left(^{\circ}\right)$----. } & & \multicolumn{3}{|c|}{ - } \\
\hline 25 Sept. & $12.6 \mathrm{~b}^{\mathrm{z}}$ & $12.8 \mathrm{~b}$ & 25 Sept. & $12.1 \mathrm{a}$ & $13.0 \mathrm{a}$ & $13.6 \mathrm{a}$ \\
\hline 10 Oct. & $12.6 \mathrm{~b}$ & $13.0 \mathrm{ab}$ & 27 Oct. & $11.4 \mathrm{~b}$ & $12.2 \mathrm{~d}$ & $12.8 \mathrm{c}$ \\
\hline 12 Nov. & $12.5 \mathrm{~b}$ & $12.7 \mathrm{bc}$ & 19 Nov. & $11.6 \mathrm{~b}$ & $12.4 \mathrm{~cd}$ & $13.1 \mathrm{bc}$ \\
\hline 8 Dec. & $12.4 \mathrm{~b}$ & $12.4 \mathrm{c}$ & 9 Dec. & $11.6 \mathrm{~b}$ & $12.6 \mathrm{bc}$ & $12.8 \mathrm{c}$ \\
\hline Nonsprayed & $13.3 \mathrm{a}$ & $13.3 \mathrm{a}$ & Nonsprayed & $12.1 \mathrm{a}$ & $12.9 \mathrm{ab}$ & $13.4 \mathrm{ab}$ \\
\hline
\end{tabular}

${ }^{2}$ Means followed by a different letter are significantly different within columns by Duncan's new multiple range test, $P \leq 0.05$. Means of a $4 \mathrm{~L} /$ tree juice sample from 12 trees/treatment.

$\times$ juice weight) per weight of whole fruit (Wardowski et al., 1995). In this study, treatments sometimes reduced yield of solids if they did not increase juice yield but did reduce juice Brix (data not shown). None of the treatments increased yield of solids compared to non-sprayed fruit.

Applications of $\mathrm{GA}_{3}$ in 1998 did not delay flowering of 'Hamlin' orange in 1999 (Table 10). In contrast, all $\mathrm{GA}_{3}$ applications delayed flowering of 'Pineapple', and late September and mid-November sprays delayed flowering of 'Valencia' trees. Gibberellic acid applied between November and January may inhibit citrus flower induction (Monselise and Halevy, 1964) as may the presence of fruit (GarciaLuis et al., 1986). Thus, the cultivar's differential response to $\mathrm{GA}_{3}$ might be related to its harvest time. In 1999, 'Hamlin' fruit were harvested in February but 'Pineapple' fruit were harvested in March (a few weeks prior to anthesis) and 'Valencia' fruit were not harvested until May (postanthesis). Garcia-Luis et al. (1986) contended that the fruit of a parthenocarpic cultivar of Citrus unshiu only inhibited flowering until they have completed peel color development. This does not appear to be the case in our study, however, because all $\mathrm{GA}_{3}$ treatments delayed peel color development of 'Hamlin' through 17 Feb. but only two $\mathrm{GA}_{3}$ treatments delayed peel color development of 'Pineapple' by that date.

In conclusion, $\mathrm{GA}_{3}$ applied at about color break can enhance juice yield of 'Hamlin' and 'Valencia' oranges that are harvested 2 to 5 months later. Treatment effects on juice yield were variable but effective application and harvest dates were consistent with previous studies (Davies et al., 1997, 1999, 2001). However $\mathrm{GA}_{3}$ treatments also resulted in lower juice Brix in some cases, and yield of solids was sometimes reduced if treatments that re-
Table 10. Flower rating of 'Hamlin', 'Pineapple', and 'Valencia' oranges, 1 Apr. 1999. ${ }^{\text {' }}$

\begin{tabular}{lccc}
\hline \hline $\mathrm{GA}_{3}$ application & \multicolumn{3}{c}{ Flower rating } \\
\cline { 2 - 4 } date, 1998 & Hamlin & Pineapple & Valencia \\
\hline 2 Sept. & $7.5 \mathrm{a}^{\mathrm{y}}$ & $2.7 \mathrm{~b}$ & --- \\
25 Sept. & $8.8 \mathrm{a}$ & $3.3 \mathrm{~b}$ & $3.8 \mathrm{~b}$ \\
27 Oct. & $9.0 \mathrm{a}$ & $2.8 \mathrm{~b}$ & $5.0 \mathrm{ab}$ \\
19 Nov. & $7.8 \mathrm{a}$ & $2.6 \mathrm{~b}$ & $2.9 \mathrm{~b}$ \\
9 Dec. & --- & -- & $4.3 \mathrm{ab}$ \\
Non-sprayed & $8.7 \mathrm{a}$ & $6.5 \mathrm{a}$ & $6.8 \mathrm{a}$ \\
\hline
\end{tabular}

${ }^{2} \mathrm{~A}$ scale of 1 to 10 was used to classify the stage of flowering with $1=$ no open flowers, $2=25 \%$ open flowers, $3=50 \%$ open flowers, $4=75 \%$ open flowers, $5=$ full bloom, $6=25 \%$ petal fall, $7=50 \%$ petal fall, $8=75 \%$ petal fall, $9=100 \%$ petal fall, 10 $=$ initial fruit set.

${ }^{y}$ Means followed by a different letter are significantly different within columns by Duncan's new multiple range test, $P \leq 0.05$. Values are treatment means, 12 trees/treatment.

duced juice Brix did not increase juice yield. Additional research is needed to determine whether the positive effects of $\mathrm{GA}_{3}$ treatment on juice yield may be separated from negative effects on juice Brix. Treatments delayed flowering of 'Pineapple' and 'Valencia' but not 'Hamlin', possible because 'Hamlin' fruit were harvested earlier than the other cultivars.

\section{Literature Cited}

Braddock, R.J. 1999. Handbook of citrus by-products and processing technology. Wiley, N.Y.

Cary, P.R. 1975. Citrus fruit maturity. Austral. Citrus News, April:10.

Coggins, C.W. 1969. Gibberellin research on citrus rind aging problems. Proc. First Intl. Citrus Symp. 3:1177-1185.

Coggins, C.W. and H.Z. Hield. 1958. Gibberellin on orange fruit. Calif. Agr. 12:11.

Coggins, C.W. and W.W. Jones. 1977. Growth 
regulators and coloring of citrus fruits. Proc. Intl. Soc. Citricult. 2:686-688.

Coggins, C.W. and L.N. Lewis. 1965. Some physical properties of the navel orange rind as related to ripening and to gibberellic acid treatments. Proc. Amer. Soc. Hort. Sci. 86:272-279.

Davies, F.S. 1986. Growth regulator improvement of postharvest quality, p. 79-99. In: Fresh citrus fruit. W. Wardowski, S. Nagy, and W. Grierson (eds.). AVI Press, Westport, Conn.

Davies, F.S., C.A. Campbell, and G. Zalman. 1997. Gibberellic acid sprays for improving fruit peel quality and increasing juice yield of processing oranges. Proc. Fla. State. Hort. Soc. 110:16-21.

Davies, F.S., C.A. Campbell, and M.W. Fidelibus. 2001. Gibberellic acid tank mix and adjuvant effects on peel quality and juice yield of 'Hamlin' oranges. HortTechnology 11:171-174.

Davies, F.S., C.A. Campbell, G. Zalman, and M Fidelibus. 1999. Gibberellic acid application timing effects on juice yield and peel quality of 'Hamlin' oranges. Proc. Fla. State Hort. Soc. 112:22-24.

El-Otmani, M. and C.W. Coggins. 1991. Growth regulator effects on retention of quality of stored citrus fruits. Scientia Hort. 45:261-272.

El-Otmani, M., C.W. Coggins, and I.L. Eaks. 1986 Fruit age and gibberellic acid effect on epicuticular wax accumulation, respiration, and internal atmosphere. J. Amer. Soc. Hort. Sci. 111:228 232

Garcia-Luis, A.M., M. Augusti, V. Almela, E. Romero, and J.L. Guardiola. 1985. Effect of gibberellic acid on ripening and peel puffing in 'Satsuma' mandarin. Scientia Hort. 27:75-86.

Garcia-Luis, A., V. Almela, C. Monerri, M. Agusti, and J.L. Guardiola. 1986. Inhibition of flowering in vivo by existing fruits and applied growth regulators in Citrus unshiu. Physiol. Plant. 66:515-520.

Greenberg, J.S., Y. Oren, G. Eshel, and E.E. Goldschmidt. 1992. Gibberellin $\mathrm{A}_{3}\left(\mathrm{GA}_{3}\right)$ on 'Minneola' tangelo; extension of the harvest season and improvement of fruit quality. Proc. Intl. Soc. Citricult. 456-458.

Huff, A. 1984. Sugar regulation of plastid interconversions in epicarp of citrus fruit. Plant Physiol. 76:307-312.

Lewis, L.L., C.W. Coggins, C.K. Labanauskas, and W.M. Dugger. 1967. Biochemical changes as- sociated with natural and gibberellin $\mathrm{A}_{3}$ delayed senescence in the navel orange rind. Plant Cell Physiol. 8:151-160.

Monselise, S.P. and A.H. Halevy. 1964. Chemical inhibition and promotion of citrus flower bud induction. Proc. Amer. Soc. Hort. Sci. 84:141146.

Monselise, S.P., M. Weiser, N. Shafir, R. Goren, and E.E. Goldschmidt. 1976. Creasing of orange peel-Physiology and control. J. Hort. Sci. 51:341-351.

Pozo, L., W.J. Kender, J.K. Burns, U. Hartmond, and A. Grant. 2000. Effects of gibberellic acid on ripening and rind puffing in 'Sunburst' mandarin. Proc. Fla. State Hort. Soc. 113:102-105.

Sites, J.W. and H.J. Reitz. 1950. The variation in individual 'Valencia' oranges from different locations on the tree as a guide to sampling methods and spot picking for quality. II. Titratable acid and the soluble solids/titratable acid ratio of the juice. Proc. Amer. Soc. Hort. Sci. 55:73-80.

Wardowski, W., J. Whigham, W. Grierson, and J. Soule. 1995. Quality tests for Florida citrus. Univ. of Florida Coop. Ext. Serv. SP99. 